\title{
DEVELOPMENT OF A SERVICE QUALITY SCALE FOR PHARMACEUTICAL SUPPLY CHAINS
}

\section{Niaz Ahmad*, Muhammad Usman Awan*, Abdul Raouf* \& Leigh Sparks**}

* Institute of Quality \& Technology Management, University of the Punjab, Lahore, Pakistan

** Institute for Retail Studies, University of Stirling, Stirling, UK

\section{Correspondence Address:}

Muhammad Usman Awan

Institute of Quality \& Technology Management

University of the Punjab

Lahore

Pakistan

usman@iqtm.pu.edu.pk 


\section{DEVELOPMENT OF A SERVICE QUALITY SCALE FOR PHARMACEUTICAL SUPPLY CHAINS}

\section{ABSTRACT}

Purpose - To develop a scale for the measurement of service quality in pharmaceutical supply chains.

Methodology / approach - 413 pharmaceutical retailers working in the 2 biggest cities of Pakistan responded to a survey. Confirmatory factor analysis developed a valid and reliable service quality measurement scale with 4 dimensions and 10 items.

Findings - Findings of this research are consistent with other service quality studies. There is no universal set of dimensions and items that determine service quality across a section of service industries. Service quality measurement must be adapted to fit the context.

Research limitations / implications - Convenience sampling was undertaken for this research. This research contributes to the measurement of service quality by developing a valid and reliable measurement scale in a previously ignored sector.

Practical implications - The scale developed in this research can be used by pharmaceutical distribution companies in Pakistan to measure, control and improve the service quality provided to pharmaceutical retailers.

Originality / value - This research provides framework to researchers to build up more pharmaceutical supply chains service quality scale development studies in similar situations so that more concrete generalizations can be made.

Keywords - Pakistan, Service quality, measurement scale, distributors-retailers, pharmaceutical supply chains.

Paper type - Research paper. 


\section{DEVELOPMENT OF A SERVICE QUALITY SCALE FOR PHARMACEUTICAL SUPPLY CHAINS}

\section{INTRODUCTION}

- A scientific and technological revolution is taking place in the pharmaceutical industry that will enable drug makers to produce profitable new medicines. But revolutions demand adjustments, and this revolution requires the supply chains to adjust with it (Ricci and Fraser, 2006) and the pharmaceutical companies who have long been considered the laggards of the supply chains have a choice: Either they can alleviate the short-term pressures they face, or they can take a long view and recognize the real contribution the supply chains can make.

In the past pharmaceutical companies did not adopted supply chain management concepts (Geimer and Tomlinson, 2002). However now several factors are pressing pharmaceutical companies to change traditional manners of conducting business. One of these factors is that supply chain is becoming a source of competitive advantage.

Other factors make the pharmaceutical supply chains of interest to the field of economics and law for two related reasons and plethora of published literature is available about these four factors. First of the two related reasons is, the usual issues of structure, conduct and performance. When applied to the pharmaceutical industry, must take into account high rate of technology change, critical importance of patent protection, potential for market power and novel price and product competitive strategies. This raises interesting positive and normative issues related to prices, profits and public policy. Second of the two related reasons is, the industry is heavily regulated in all major functions. Much of the published literature focused on 
regulation related to safety and efficacy. Because pharmaceuticals may entail significant risks to health as well as potential benefits, all industrialized countries require that drugs meet certain safety standards as a condition of market access (Danzon, 1999). However the factor (supply chain is becoming a source of competitive advantage)is neglected in the previous research and the question "What makes the pharmaceutical supply chains a source of competitive advantage” is still unanswered.

There is consensus in the marketing literature that better service quality is a critical success factor in this era of intense competition. Service quality's conceptual and empirical link to customer satisfaction has turned it into a core marketing instrument (Venetis and Ghauri, 2004). Curiosity over the measurement of service quality is therefore high and researchers have devoted a great deal of attention to service quality research (Abdullah, 2006). Relationship of service quality with improved supply chain performance is widely accepted (Mentzer et al., 1999, 2001; Perry and Sohal,1999) because satisfaction of each member of the supply chain can be increased only by putting aside the traditional arms-length relationship and by developing closer partnership type arrangements (Christopher, 2004). In the development of such partnership type arrangements, service quality is an important tool.

Regardless of this universal recognition for realizing the importance of service quality in supply chains, it is little researched (Nix, 2001). Several authors (e.g. Sinha and Babu, 1998; Perry and Sohal, 1999; Seth et al. 2006) have attempted to expand the hypothetical sphere of service quality in a supply chain context. However, there have been very few studies (Beinstock et al.1997; Mentzer et al. 1999; Rafele, 2004) on the 
development of service quality measurement scales in supply chains. The rationale of this paper is to continue this extension of service quality scale development studies into the pharmaceutical supply chains context as this research develops a service quality measurement scale for the distributors-retailers interface of pharmaceutical supply chains. Pharmaceutical supply chains do not appear in previous supply chains specific service quality measurement scale development studies.

In this paper, first the literature review is presented focusing on dimensions of service quality. From the literature review, research objectives are stated. The methodology and context are then discussed. Data analysis is followed by conclusions, including limitations and directions for future research.

\section{LITERATURE REVIEW}

Whilst there has been considerable progress as to how service quality should be measured, there is little advancement as to what should be measured? Researchers generally have adopted one of two perspectives. These perspectives are the "Nordic perspective” and the “American perspective” (Brady and Cronin, 2001). The "Nordic perspective” was proposed by Gronroos (1984) and the “American perspective” was proposed by Parasuraman et al. (1985, 1988).

In the "Nordic perspective”, Gronroos (1984) identified 2 dimensions of service quality (technical quality and functional quality). He defined technical quality as "what the consumer receives as a result of interactions with a service firm" and identified employees technical ability, employees knowledge, technical solutions, computerised systems and machine quality as its 5 attributes. Gronroos (1984) defined functional quality as "the way in which the technical quality is transferred" and 
identified behaviour, attitude, accessibility, appearance, customer contact, internal relationships, service-mindedness as its 7 attributes. He concluded that the technical and functional quality of service built up the corporate "image" of the company.

The "Nordic perspective" of service quality was the first to be published in scholastic literature. However, the first seriously dedicated program of research to answer the questions "what's the best way to define service quality?” and "what's the best way to measure it?” was launched by Parasuraman et al. $(1985,1988)$ (Schneider and White , 2004). This program developed the "American perspective” of service quality. Parasuraman et al.(1985) built up a 34-item service quality scale comprising 10 dimensions (reliability, responsiveness, competence, access, courtesy, communication, credibility, security, understanding/knowing the customer and tangibles). Subsequent work by Parasuraman et al. (1988) resulted in the service quality measurement scale with 22-items on 5 dimensions. The dimensions reliability, responsiveness and tangibles were retained as identified in 1985 whereas communication, competence, credibility, courtesy and security merged as a new dimension "assurance”. Access and understanding / knowing the customer merged to form the dimension "empathy". Parasuraman et al. (1988) codified this scale as SERVQUAL and defined its 5 dimensions as:

Tangibility: Appearance of physical facilities, equipment and communication material.

Reliability: Ability to perform the promised service dependably and accurately. Responsiveness: Willingness to help customers and provide prompt service. 
Assurance: Knowledge and courtesy of the employees and their ability to convey trust and confidence.

Empathy: The caring and individualized attention, organization provides to its customers.

While there is no global consensus that either the "Nordic perspective" or the "American perspective" is the more appropriate approach, the "American perspective” dominates the literature (Schneider and White, 2004) because the development of the "American perspective" generated a "cottage industry" of replicative studies in various conditions, sectors and countries. Parasuraman et al. (1988) claimed that the 5 dimensions and 22 items proposed in their "American perspective” are generic in nature and applicable to all service organizations.

However, the service quality measurement scale developed by Parasuraman et al. (1988) has been the subject of criticism since its development (Johnston, 1995). Buttle (1996) provides a detailed critique of the issues surrounding the 5 dimensions of the Parasuraman et al. (1988) service quality scale, mainly on the basis of number of dimensions and contextual stability.

Carman (1990) was first researcher who found that the 5 dimensions of service quality measurement scale proposed by Parasuraman et al. (1988) are not so generic that users should not add new dimensions they believe are important. He found that if a dimension is extremely significant to customers it is possible to be decomposed into a number of sub-dimensions and vice versa. Babakus and Boller (1992) also empirically assessed the scale proposed by Parasuraman et al. (1988) and suggested 
that the number of service quality dimensions is dependent on the service being offered. Mukherjee and Nath (2005) stressed that performance of a service organization on all the dimensions of service quality may not always move in the same direction. Seth et al. (2006) summarized some of the service quality studies published from 1984 to 2000 (Table I) over a variety of service industries.

\section{(Table I about here)}

Seth et al. (2006) concluded that there seems to be no agreement on the measurement side (attributes) of service quality because different researchers propose different attributes for different applications. Chowdhary and Prakash (2007) also report variations from unidimensionality to two, three, four, six and even eight factor structures in the previous service quality studies.

Next is the issue of contextual stability. Cronin and Taylor (1992) suggest flexibility in the Parasuraman et al. (1988) service quality measurement scale items and argue that high involvement services such as healthcare or financial services have different service quality items than low involvement services such as fast food or dry cleaning. Researchers must also therefore consider the individual items of service quality for each service industry. Brady and Cronin (2001) also suggest that from a theoretical perspective, even if the 5 service quality dimensions proposed by Parasuraman et al. (1988) are generic, something specific must be reliable, responsive, empathetic, assured and tangible. To identify this "something" for each context is critical. Moreover, this scale was developed in Western culture so its contextual stability across diverse cultures is also an issue (Parikh, 2006). Based on Hofstede's 
dimensions of culture, Donthu and Yoo (1998) studied the effect of culture on consumer service quality expectations and concluded that as a consequence of cultural orientation, consumers differ in their overall expectations with regard to service quality dimensions.

On the basis of this literature review, it may therefore be concluded that despite the fact that the "American perspective" dominates the service quality literature and many service quality studies are based on the service quality measurement scale proposed by Parasuraman et al. (1988), there is actually no generic scale for measurement of service quality. There is no universal set of dimensions and items that determine the service quality across a section of service industries in different cultures, so service quality measurement must be adapted to fit the context. Therefore there is a need for the development of context specific service quality measurement scales. Such context specific service quality measurement scales may help managers to gauge, manage and improve service quality in particular sectors with more simplicity and effectiveness.

In today’s global marketplace, individual firms no longer compete as independent entities but compete as an integral part of supply chain links (Seth et al. 2006). Christopher (1992) also argued that a key aspect of business is that supply chains compete, not companies. According to Waters (2003), organizations do not work in isolation; they act as a customer when buy materials from their own suppliers and act as a supplier when they deliver materials to their own customers. A wholesaler for example acts as a customer when buying goods from manufacturers, and then acts as a supplier when selling goods to retailers. It is important to satisfy each member of the supply chain. There is a change in the landscape of supply chain management in 
recent years and satisfaction of each member of the supply chain can be increased only by putting aside the traditional arms-length relationship and by developing closer partnership type arrangements (Christopher, 2004). In the development of such partnership type arrangements, service quality is an important tool because the relationship of service quality with improved supply chain performance is widely accepted (Mentzer et al., 1999, 2001; Perry and Sohal,1999).

Regardless of this universal recognition for realizing the importance of service quality in supply chains, it is little researched (Nix, 2001). Most of the previous service quality research has been aimed at the end-use customer (Faulds and Mangold, 1995; Perry and Sohal, 1999). There have been very few studies on the development of service quality measurement scales in supply chains (Beinstock et al. 1997; Mentzer et al. 1999, Rafele, 2004). These few studies are also confined to specific sectors and are based in developed countries. Generalization of findings of these studies in the global economy is not possible without further empirical research (Rafele, 2004).

To reduce this research gap, this study is focused on service quality scale development at the distributors-retailers interface of the pharmaceutical supply chains in Pakistan. The distributors-retailers interface is chosen as it has many noncontractual dimensions in contrast to the manufacturers-distributors interface of supply chains which is frequently characterized by contractual agreements (Mangold and Faulds, 1993). Pakistan (a developing country) is selected for this study because little work has been done to examine the applicability of service quality measurement scales to the service industries in developing countries (Jain and Gupta, 2004). The 
authors could find no studies on the development of supply chain specific service quality measurement scale studies in any of the developing countries.

The aim of this research is to develop a scale for the measurement of service quality in the distributors-retailers interface of pharmaceutical supply chains using Pakistan as the context. This research will contribute to reduce the current lack of supply chain specific service quality scale development studies. It extends supply chains specific service quality scale development research into developing countries and into a new sector (distributors-retailers interface of pharmaceutical supply chains). The scale developed as an outcome of this research will assist managers in pharmaceutical distribution companies in Pakistan to gauge, manage and improve service quality.

\section{METHODOLOGY}

Churchill (1979) suggested a classical procedure for developing better measures of marketing constructs (Figure I)

(Figure I about here)

Methodology proposed by Churchill (1979) was used for this scale development research. Schneider and White (2004) also propose similar methodology. Research process started by refining the Parasuraman et al. (1988) service quality measurement scale. Focus group discussion was used for this refinement. Then on the basis of survey data, the intially developed scale was further refined through statistical techniques. 
There were several reasons for the selection of the Parasuraman et al. (1988) service quality measurement scale as the foundation in this research. According to Schneider and White (2004), the “American perspective” proposed by Parasuraman et al. (1988) dominates the service quality literature. The service quality dimensions upon which the Parasuraman et al. (1988) service quality measurement scale is based are therefore often employed when discussing and measuring service quality in a variety of service sectors (Kvist and Klefsjo, 2006). Rafele (2004) also claimed that the Parasuraman et al. (1988) service quality measurement scale is applicable to all kinds of services including supply chains.

For this particular study, the service quality measurement scale proposed by Parasuraman et al. (1988) was refined after focus group discussion. Morgan (1993) suggests such refinement of existing measurement instruments when the population for the research is new as in this case. The focus group discussion lasted for approximately two hours. Eleven pharmaceutical retailers participated in this discussion. The contact author acted as the moderator for the focus group discussion and took extensive notes of the proceedings. As a result of the focus group discussion and then subsequent evaluation of the initial drafts of the refined service quality measurement scale by statisticians, linguistic experts and the authors, a service quality measurement scale with 5 dimensions and 31 items emerged.

The number of dimensions in this refined service quality measurement scale was the same as that of Parasuraman et al. (1988) as there was consensus among the participants of the focus group discussion that these dimensions cover all dimensions of service quality in the distributors-retailers interface of pharmaceutical supply chains in Pakistan. However the number of items in the refined scale was increased to 
31 as compared to 22 in the Parasuraman et al. (1988) service quality measurement scale. Nine new items were added on the basis of sectoral relevance. Several of the existing items were modified to increase the ability of practitioners to visualize the content of items. Of the 31 items in this initially refined service quality measurement scale, 10 dealt with reliability, 5 with tangibles, 7 with assurance, 5 with empathy and 4 with responsiveness. On the recommendation of the focus group participants each item in the survey questionnaire was written in English as well as in Urdu (national language of Pakistan). Service quality dimensions were not specified on the survey questionnaire as focus group participants thought that this may increase complexity for respondents. The scale used in the refined questionnaire was a 7 - point numeric response scale $(1=$ extremely unimportant, 7 = extremely important). Items used in the questionnaire along with dimensions and abbreviations used for data analysis are given in Table II.

(Table II about here)

Once the questionnaire was finalized, the next issue was sampling. In Pakistan, the pharmaceutical industry is a sizeable industry producing 125 categories of medicines with an annual turnover of US\$ 1.2 billion and an annual growth rate of 10-15\% (Hameed 2007). The total number of pharmaceutical companies is 379, of which 350 are local companies and 29 are multinational companies. There are 350 pharmaceutical distribution centres in different cities of Pakistan (Qassim, 2005) and these distributors distribute medicines to 45000 - 50000 retail outlets (Butt et al. 2005).

For survey research, probability sampling is preferred over non-probability sampling (Saunders et al. 2000). However according to Trochim (2006) there may be 
circumstances where it is not feasible, practical or theoretically sensible to undertake probability sampling. This study is the first known research study related to service quality in the distributors-retailers interface of pharmaceutical supply chains in Pakistan. Because of the lack of a reliable sampling frame, non-probability purposiveconvenience sampling was undertaken. The two biggest cities of Pakistan (Karachi and Lahore - with more then $15 \%$ of country's population) were selected for the survey. People from all over Pakistan come to these metropolitan cities for the treatment of their medical ailments. The pharmaceutical retail business in these two cities is much more developed as compared to the rest of the country. Pharmaceutical distributors therefore focus particularly on having good working relationship with pharmaceutical retailers operating in these two cities.

Two pharmaceutical distribution companies (based one each at Karachi and Lahore) were contacted to support the data collection process. These 2 pharmaceutical distribution companies had 1050 pharmaceutical retailers on their distribution lists. Questionnaires along with a covering letter were provided to these pharmaceutical distribution companies. The sales force of these 2 pharmaceutical distribution companies distributed these questionnaires to the pharmaceutical retailers and then collected the filled questionnaires after one week. Questionnaire delivery and collection method was used for this survey because this method helps to increase response rate (Saunders et al. 2000). Out of 1050 distributed questionnaires, 413 filled questionnaires were received back. The response rate was $39.3 \%$, which is an acceptable response rate.

\section{DATA ANALYSIS}


The first step in the data analysis was to group the questionnaire items according to the 5 service quality dimensions agreed in the focus group discussion. The primary approach for scale purification when a theoretical foundation drives survey development is to rely on Confirmatory Factor Analysis (CFA) to ensure scale unidimensionality, followed by scale reliability and construct validity assessments (Anderson and Gerbing, 1982). The next step was therefore CFA to ensure scale unidimensionality. The Structural Equation Modeling (SEM) program AMOS 7.0 was used for data analyses.

The covariance matrix between the 5 service quality dimensions was created. (Figure II).

(Figure II about here)

Seven runs of CFA were conducted. The process continued until satisfactory goodness of fit statistics was obtained. During this process, one dimension (empathy) completely disappeared. In total, 21 of an initial 31 items were deleted. This intensity of item deletion is not exceptional in scale development studies as the final scale may contain even one fifth of the original items (Bienstock et al., 1997).

The sequence list of 21 items deleted is attached as appendix A. The number of items deleted in each run was 4, 4, 3, 4, 3 and 3. Each item deleted affects all other items also, so only a few items were deleted per CFA run. These items were found to be inadequate on model estimates examination by researchers after each CFA run based on the amount of explained variance. The lower the amount of explained variance for any item, the more poorly it is loaded in the model, thus making it a choice for 
deletion from the model. Amount of explained variance for deleted items is also mentioned in the appendix A along with the deletion step no.

After the deletion of the 21 items, a valid scale with 4 dimensions and 10 items emerged (Figure III).

(Figure III about here)

The scale emerged after CFA was assessed for goodness for fit statistics. According to Sila and Ebrahimpour (2005), empirical evidence in CFA is generally assessed using criteria such as the Comparative Fit Index (CFI), the Root Mean Square Error of Approximation (RMSEA), the significance of parameter estimates, and the amount of squared multiple correlations.

CFI: This index compares the proposed model with a null model assuming that there are no relationships between the measures. A CFI value greater then 0.90 indicates an acceptable fit to the data (Bentler, 1992). CFA model developed in this analyses indicates CFI value (0.98) which suggests a very good model fit.

RMSEA: RMSEA is an index used to assess residuals and adjusts parsimony in the model. Its value must be equal to or less than 0.08 for an adequate model fit (Hu and Bentler, 1999). In the CFA model developed, RMSEA value is 0.065 indicating adequate model fit.

Parameter estimates: All the factor loadings in the CFA model developed are statistically significant at 0.001 level of significance. 
Amount of squared multiple correlation: The amount of squared multiple correlations for all dimensions in the model developed range from 0.62 to 0.92 thus indicating acceptable squared factor loadings.

Once the unidimensionality of the scale developed was demonstrated using CFA, the reliability of the scale developed was evaluated by the determination of Cronbach's coefficient alpha. In general reliability coefficients of 0.70 or more are considered adequate (Cronbach, 1951; Nunnally, 1978). The overall value of Cronbach's coefficient alpha for the 10 items in the scale developed after CFA is 0.91 . This value is acceptable. Each sub-scale also has Cronbach’s coefficient alpha value above 0.70 (reliability $=0.92$, assurance $=0.85$, tangibles $=0.94$, responsiveness $=0.87$ )

According to Mentzer et al. (1999), Cronbach's coefficient alpha is a meaningless calculation with a two or less item scale, since its purpose is to compare each item to the remaining items in the scale as a group. So, Item to Total Correlations (ITC) were evaluated for the sub-scales "reliability" and "responsiveness" as these sub-scales have only two items. All these values are above 0.70 so all ITC values are acceptable.

After assessing unidimensionality and reliability, the next issue was to assess content, convergent and discriminant validity of the scale developed. According to Nunnally (1978), content validity depends on how well the researchers created measurement items using the relevant literature to cover the content domain of the variable being measured. The evaluation of content validity is therefore a judgmental process not open to numerical evaluation (Mahour, 2006). As mentioned previously the selection of dimensions and items in this study was based on the Parasuraman et al. (1988) 
service quality measurement scale extensively used in published service quality literature. Subsequent refinement of this widely used scale occurred through focus group discussion with representatives of pharmaceutical retailers. The instrument thus has strong content validity.

According to Ahire et al. (1996) convergent validity measures the extent to which different approaches to measuring a construct produces the same results. A value of 0.60 or higher for all factor loadings in CFA model developed demonstrates strong convergent validity (Chin et al. 1996). In the CFA model developed, all the factor loadings ranged from 0.79 to 0.96 so all items in the scale developed have strong convergent validity.

Discriminant validity measures the degree to which a construct and its indicators are different from another construct and its indicators (Bagozzi et al., 1991). Evidence of discriminant validity can be assessed in multiple ways (Mentzer et al., 1999). One of the ways is by comparing the Cronbach's alpha of a construct to its correlations with other model variables (Sila and Ebrahimpour, 2005). According to Ghiselli et al. (1981), if the value of alpha is sufficiently larger than the average of its correlations with other variables, this is evidence of discriminant validity. The difference between the alpha value of each construct and the average correlation of each construct with the other constructs was adequately large (reliability $=0.43$, assurance $=0.32$, tangibles $=0.39$, responsiveness $=0.38)$. According to Sila and Ebrahimpour (2005) all these values are acceptable for discriminant validity.

Assessment of unidimensionality using goodness of fit statistics, scale reliability and construct validity (content validity, convergent validity and discriminant validity) 
therefore confirmed that the model which emerged during CFA (figure 1) is good model. It has 4 dimensions (reliability, assurance, tangibles, responsiveness) and 10 items. This model constitutes a service quality scale for measurement of service quality in the distributors-retailers interface of pharmaceutical supply chains in Pakistan. The list of 10 items which emerged in the CFA model (figure 1) is given in Table III.

(Table III about here)

\section{CONCLUSION}

This research resulted in the development of a valid and reliable scale for measuring service quality in the distributors-retailers interface of pharmaceutical supply chains in Pakistan. The literature review concluded that despite of wide acceptance of the “American perspective” of service quality proposed by Parasuraman et al. (1988), service quality measurement must be adapted to fit the context as there is no universal set of dimensions and items that determine the service quality across a section of industries and cultures. The findings of this research confirms this conclusion as the service quality measurement scale developed in this research has four service quality dimensions only and the dimension “empathy” proposed by Parasuraman et al. (1988) did not emerge as a significant dimension in the scale developed in this study.

Like all other studies, this research has limitations. The data was obtained from those pharmaceutical retailers only which were on the panel of the pharmaceutical distributors supporting this research. There may be pharmaceutical retailers which are not on this panel and therefore may be excluded from the survey sample. This study 
was limited to the 2 biggest cities of Pakistan only. For pharmaceutical retailers working in small cities, service quality dimensions may be different from those identified in this research.

Nonetheless, the findings of this study should be useful for both practitioners and researchers. Practitioners (pharmaceutical distributors) can use this service quality measurement scale to evaluate the extent of service quality they provide to their customers (pharmaceutical retailers) and to spot those dimensions and items of service quality where their organizations require improvement.

For researchers, this study contributes significantly to the existing supply chains specific service quality scale development literature by developing a service quality measurement scale for a previously neglected sector. This study identified that "empathy" is not a critical dimension of service quality in distributors-retailers interface of pharmaceutical supply chains in Pakistan. In investigating the perception of pharmaceutical retailers regarding the dimension "empathy”, qualitative studies are recommended so that the reasons for non emergence of "empathy" as the significant service quality dimension may be identified. One possible reason for distributors not to be "empathetic" is monopoly of pharmaceutical companies in the market. Studies could also be conducted in the distributors-retailers interface of pharmaceutical supply chains in other cities of Pakistan and in other countries to see whether the service quality dimensions and items identified in this study are significant elsewhere in such situations. By building up the number of such studies more concrete generalizations can be made. 


\section{REFERENCES}

Abdullah, F. (2006), "Measuring service quality in higher education: HEdPERF versus SERVPERF”, Marketing Intelligence \& Planning, Vol. 24 No. 1, pp. 31-47.

Ahire, S.L., Golhar, D.Y. and Waller, M.A. (1996), "Development and validation of TQM implementation constructs”, Decision Sciences, Vol. 27 No. 1, pp.23-56.

Anderson, J.C. and Gerbing, D.W. (1982), "Some methods for respecifying measurement models to obtain unidimensional construct measurement”, Journal of Marketing Research, Vol. 19 No. 4, pp.453-60.

Babakus, E. and Boller, G.W.(1992), “ An empirical assessment of the SERVQUAL scale”, Journal of business review, Vol. 24, pp.253-68.

Bagozzi, R.P., Yi, Y. and Phillips, L.W. (1991), “Assessing construct validity in organizational research”, Administrative Sciences Quarterly, Vol. 36 No. 2, pp.42158.

Beinstock, C.C., Mentzer, J.T. and Bird, M.M. (1997), "Measuring physical distribution service quality”, Journal of Academy of Marketing Science, Vol. 25 No. 1, pp. 31-44.

Bentler, P.M. (1992), "On the fit of models to covariances and methodology to the bulletin”, Psychological bulletin, Vol. 112 No. 3, pp.400-04.

Brady, M.K. and Cronin, J.J. (2001), "Some new thoughts on conceptualizing perceived service quality: a hierarchial approach”, Journal of Marketing , Vol. 65 No. 3, pp.34-49.

Butt, Z.A., Gilani, A.H., Nanan, D., Sheikh, A.L. and White, F. (2005), "Quality of pharmacies in Pakistan”, International Journal for Quality in Health Care, Vol. 17 No. 4, pp. 307-13.

Buttle, F. (1996), “SERVQUAL: review, critique, research agenda”, European Journal of Marketing, Vol. 30 No. 1, PP. 8-32.

Carman, J. (1990), "Consumer perceptions of service quality: an assessment of the SERVQUAL dimensions”, Journal of Retailing, Vol. 66 No. 1, pp. 33-55.

Chin, W.W., Marcolin, B.L. and Newsted, P.R. (1996), “A partial least squares latent variable modeling approach for measuring interaction effects: results from a Monte Carlo simulation study and voice mail emotion / adaptation study", Proceedings of Seventeenth International Conference of Information Systems, Cleveland, OH, pp. 2141.

Chowdhary, N. and Prakash, M. (2007), "Prioritizing service quality dimensions", Managing Service Quality, Vol. 17 No. 5, pp. 493-509.

Christopher, M. (1992), Logistics \& Supply Chain Management, Pitmans, London. 
Christopher, M. and Lee, H. (2004), "Mitigating supply chain risk through improved confidence", International Journal of Physical Distribution and Logistics Management, Vol. 34 No. 5, pp.388-96.

Churchill Jr., G. A. (1979), “A paradigm for developing better measures of marketing constructs”, Journal of Marketing Research Vol. 16, pp. 64-73.

Cronbach, L.J. (1951), "Coefficient alpha and the internal structure of test”, Psychometrica, Vol. 16 No. 3, pp. 297-300.

Cronin, J.J. and Taylor, S.A. (1992), "Measuring service quality: a reexamination and extension”, Journal of Marketing, Vol. 56 No. 3, pp. 55-68.

Dabholkar, P.A., Shepherd, C.D. and Thorpe, D.I. (2000), “A comprehensive framework for service quality: an investigation of critical conceptual and measurement issues through a longitudinal study”, Journal of Retailing,Vol. 76 No. 2, pp. 131-69.

Danzon, P.M.(1999),"5880 - The pharmaceutical industry", viewed on December 10 2008, <http://encyclo.findlaw.com/5880book.pdf>

Donthu, N. and Yoo, B. (1998), "Cultural influences on service quality expectations”, Journal of Service Research, Vol. 1 No. 2, pp. 178-86.

Ennew, C.T., Reed, G.V. and Binks, M.R. (1993), "Importance - performance analysis and the measurement of service quality", European Journal of Marketing,Vol. 27 No. 2, pp. 59-70.

Faulds, D.J. and Mangold, W.G. (1995), "Service quality in the distributor-retailer dyad: empirical results”, Journal of Marketing Channels, Vol. 4 No. 3, pp. 95-112.

Geimer, H. and Tomlinson, G. (2002), “The neglected pharmaceutical supply chains”, viewed on 06 December 2008, <http://web.ebscohost.com/ehost/detail?vid=4\&hid=104\&sid=6e62635a-dc79-4610b114-28ecb2743ea9\%40SRCSM1\&bdata=JnNpdGU9ZWhvc3QtbGl2ZQ\%3d\% $\underline{3 d \# d b=b u h \& A N=8870553>}$

Ghiselli, E.E., Campbell, J.P. and Zedeck, S. (1981) Measurement Theory for the Behavioral Sciences, Freeman, San Francisco.

Ghobadian, A. (1994), “Service quality concepts and models”, International Journal of Quality and Reliability Management, Vol. 11 No. 9, pp. 43-66.

Gronroos, C. (1984), “A service quality model and its marketing implications”, European Journal of Marketing, Vol. 18 No. 4, pp.36-44.

Hameed, A. (2007), Pharmacoeconomics and outcomes research in Pakistan, paper presented to the ISPOR Second Asia Pacific Conference, Shanghai, 5-7 March. 
Haywood-Farmer, J. (1988), “A conceptual model of service quality”, International Journal of Operations and Production Management, Vol. 8 No. 6, pp. 19-29.

Hu, L. and Bentler, P.M. (1999), "Cutoff criteria for fit indexes in covariance structure analysis: conventional criteria versus new alternatives”, Structural Equation Modeling, Vol. 6 No. 1, pp.1-55.

Jain, S.K. and Gupta, G. (2004), "Measuring service quality: SERVQUAL vs SERVPERF scales”, Vikalpa; The Journal for Decision Makers,

Johnston, R. (1995), “The determinants of service quality: satisfiers and dissatisfiers”, International Journal of Service Industry Management”, Vol. 6 No. 5, pp. 53-71.

Kvist, A.K.J. and Klefsjo, B. (2006), "Which service quality dimensions are important in inbound tourism?”, Managing Service Quality, Vol. 16 No. 5, pp. 520-37.

Lehtinen, U. and Lehtinen, J.R. (1991), “Two approaches to service quality dimensions”, The Service Industries Journal, Vol. 11 No. 3, pp. 287-305.

Mahour, M.P. (2006), “The Effect of Quality Management Practices on Operational and Business Results in the Petroleum Industry in Iran”, PhD thesis, University of Nebraska, Lincoln.

Mangold, W. Glynn and David J. Faulds (1993), "Service Quality in a Retail Channel System", Journal of Services Marketing, Vol. 7 No. 4, pp. 4-10.

Mentzer, J.T., Flint, D.J. and Kent, J.L. (1999), "Developing a logistics service quality scale”, Journal of Business Logistics, Vol. 20 No. 1, pp. 9-32.

Mentzer, J.T., Flint, D.J. and Tomas, M.H. (2001), "Logistics service quality as a segment-customized process”, Journal of Marketing, Vol. 65 No. 4, pp. 82-104.

Mersha, T. and Adlakha, V. (1992), "Attributes of service quality: the consumers perspective”, International Journal of Service Industry Management”, Vol. 3 No. 3, pp. 34-45.

Morgan, D.L. (1993), Successful focus groups: Advancing the state of the art, Sage, London.

Mukherjee, A. and Nath, P. (2005), "An empirical assessment of comparative approaches to service quality measurement”, Journal of Services Marketing”, Vol. 19 No. 3, pp. 174-184.

Nix, N. (2001), “Customer service in supply chain management context”, in Mentzer, J.T. (Ed.), Supply Chain Management, Sage, New York, pp. 358-9.

Nunnally, J.C. (1978), Psychometric theory, Mc Graw-Hill, London. 
Parasuraman, A., Zeithaml, V.A. and Berry, L.L. (1985), “A conceptual model of service quality and its implications for future research”, Journal of Marketing, Vol. 49 No. 3, pp.41-50.

Parasuraman, A., Zeithaml, V.A. and Berry, L.L. (1988), "SERVQUAL: a multipleitem scale for measuring customer perceptions of service quality”, Journal of Retailing, Vol. 64 No. 1, pp.12-37.

Parikh, D. (2006), "Measuring retail service quality" an empirical assessment of the instrument”, Vikalpa; The Journal for Decision Makers, Vol. 31 No. 2, pp. 45-55.

Perry, M. and Sohal, A. (1999), "Improving service quality within the supply chain: an Australian study”, Total Quality Management,Vol. 10 Nos 4/5, pp. 673-9.

Philip, G. and Hazlett, S.A. (1997), “The measurement of service quality:a new P-C-P attributes model”, International Journal of Quality and Reliability Management, Vol. 14 No. 3, pp. 260-86.

Qassim, E. (2005), Retail trade feels the heat as new product launches glore, viewed 30 July 2007, <www.pharmabiz.com/article/detnews.asp?articleid=28361\&sectionid $=50>$.

Rafele, C. (2004), "Logistic service measurement: a reference framework”, Journal of Manufacturing Technology Management, Vol. 15 No. 3, pp. 280-90.

Ricci, M.T. and Fraser, H.E. (2006), Revolution in the pharmaceutical supply chain, viewed on 06 December 2008, <www.dddmag.com/revolution-in-thepharmaceutical.aspx $>$.

Rosen, L.D. and Karwan, K.R. (1994), "Prioritizing the dimensions of service quality”, International Journal of Service Industry Management”, Vol. 5 No. 4, pp. 39-52.

Saunders, M.N.K., Lewis, P. and Thornhill, A. (2000), Research Methods for Business Students, Prentice Hall, London.

Schneider, B. and White, S.S. (2004), Service Quality - Research Perspectives, Sage, London.

Seth, N., Deshmukh, S.G. and Vrat, V. (2006), “A conceptual model for quality of service in the supply chain", International Journal of Physical Distribution and Logistics Management, Vol. 36 No. 7, pp.547-75.

Sila, I. and Ebrahimpour, M. (2005), “Critical linkages among TQM factors and business results”, International Journal of Operations and Production Management, Vol. 25 No. 11, pp.1123-55.

Sinha, R.K. and Babu, A.S. (1998), "Quality of customer service in a supply chain system”, International Journal of Quality \& Reliability Management, Vol. 15 No. 8/9, pp. 844-59. 
Trochim, W. (2007), Non probability sampling, viewed on 05 July 2007, $<$ www.socialresearchmethods.net/kb/sampnon.htm>.

Venetis, K.A. and Ghauri, P.N. (2004), “Service quality and customer retention: building long-term relationships”, European Journal of Marketing, Vol. 38 No. 11/12, pp. 1577-98.

Waters, D. (2003), Logistics: An Introduction to Supply Chain Management, Palgrave, New York. 


\section{TABLE I: ATTRIBUTES OF SERVICE QUALITY}

\begin{tabular}{|c|c|c|}
\hline RESEARCHERS & SECTOR STUDIED & ATTRIBUTES \\
\hline Gronroos (1984) & 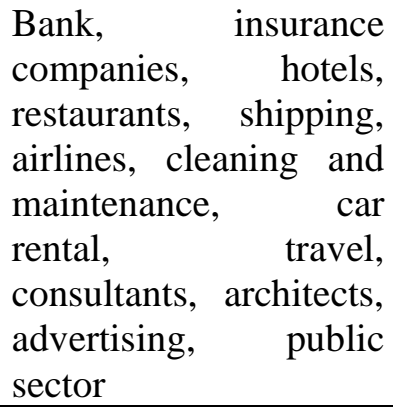 & Technical quality, functional quality, corporate image \\
\hline $\begin{array}{l}\text { Parasuraman et al. } \\
\text { (1985) }\end{array}$ & $\begin{array}{l}\text { Banking, credit card, } \\
\text { security brokerage, } \\
\text { product repair and } \\
\text { maintenance }\end{array}$ & $\begin{array}{l}\text { Credibility, access, reliability, communication, understanding the customer, courtesy, } \\
\text { competence, responsiveness, tangibles, security }\end{array}$ \\
\hline $\begin{array}{l}\text { Parasuraman et al. } \\
(1988)\end{array}$ & $\begin{array}{l}\text { Appliance repair and } \\
\text { maintenance, retail } \\
\text { banking, long-distance } \\
\text { telephone, securities } \\
\text { brokerage, and credit } \\
\text { cards. }\end{array}$ & Assurance, responsiveness, tangibles, reliability, empathy \\
\hline $\begin{array}{l}\text { Haywood-Farmer } \\
\text { (1988) }\end{array}$ & Theoretical paper & $\begin{array}{l}\text { Behavioral aspects (Timeliness, speed, communication verbal, non-verbal), courtesy, } \\
\text { warmth, friendliness, tact, attitude, tone of voice, dress, neatness, politeness, } \\
\text { attentiveness, anticipation, handling complaints, solving problems), professional judgement } \\
\text { (diagnosis, advice, skill, guidance, innovation, honesty, confidentiality, flexibility, discretion, } \\
\text { knowledge), physical facilities and processes (location, layout, de'cor, size, facility } \\
\text { reliability, process flow, capacity, balance, control of flow, process flexibility, timeliness, } \\
\text { speed, ranges of services offered, communication) }\end{array}$ \\
\hline
\end{tabular}




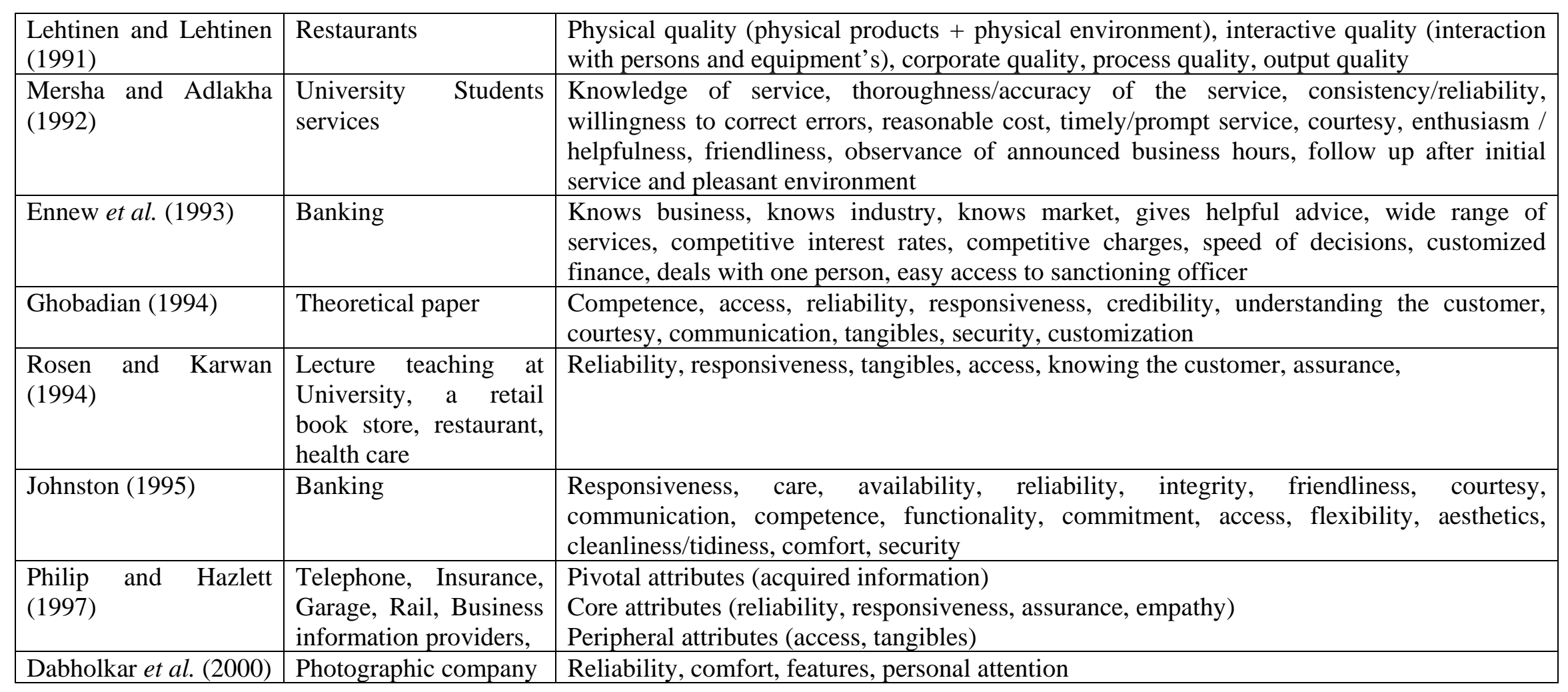

\section{Source: Seth et al. (2006)}




\section{TABLE II: QUESTIONNAIRE ITEMS (ALONG WITH DIMENSIONS AND ABBREVIATIONS USED IN ANALYSIS)}

\begin{tabular}{|l|l|l|}
\hline$\underline{\text { S.No }}$ & $\underline{\mathbf{I T E M}}$ & $\begin{array}{l}\text { DIMENSION } \\
\text { ABBREVIATION } \\
\text { USED }\end{array}$ IN \\
\hline 1. & Distribution centre has modern equipment (Computers, air-conditioning etc.). & Tangible (TAN1) \\
\hline 2. & Distributor has sufficient physical facilities for storing drug products. & Tangible (TAN2) \\
\hline 3. & The physical facilities at distribution centre are visually clean. & Tangible (TAN3) \\
\hline 4. & Vehicles used in transportation are visually in a good condition. & Tangible (TAN4) \\
\hline 5. & Personnel handling drugs are professional in appearance. & Tangible (TAN5) \\
\hline 6. & Personnel at the distribution centre are trained. & Assurance (ASS1) \\
\hline 7. & Temperature and humidity are controlled during transportation of drugs. & Reliability (REL1) \\
\hline 8. & Order taking methods (including frequency) are accurate. & Assurance (ASS2) \\
\hline 9. & Order delivery methods (including frequency) are accurate. & Assurance (ASS3) \\
\hline 10. & When distributor promises to deliver by certain time, they do so. & Responsiveness (RES1) \\
\hline 11. & When you have any problem, distributor shows a sincere interest in solving it. & Reliability (REL2) \\
\hline 12. & Shipments contain wrong / damaged items. & Reliability (REL3) \\
\hline 13. & Shipments contain incorrect quantity. & Reliability (REL4) \\
\hline 14. & Distributor effectively handles the expired drugs issue. & Reliability (REL5) \\
\hline 15. & Distributor effectively handles the counterfeit drugs issue. & Reliability (REL6) \\
\hline
\end{tabular}




\begin{tabular}{|l|l|l|}
\hline 16. & Distributor responds immediately to your enquiries. & Responsiveness (RES2) \\
\hline 17. & Distributor responds immediately to your complaints. & Responsiveness (RES3) \\
\hline 18. & Distributor provide services at short notice (if required) & Responsiveness (RES4) \\
\hline 19. & Personnel in the distribution centre are consistently courteous with you & Assurance (ASS4) \\
\hline 20. & Personnel in the distribution centre have the knowledge to answer your queries. & Assurance (ASS5) \\
\hline 21. & Personnel in the distribution centre have the authority to solve your problems. & Assurance (ASS6) \\
\hline 22. & Distribution centre personnel's give you individual attention & Empathy (EMP1) \\
\hline 23. & Distribution centre personnel's fulfils your specific requirements & Empathy (EMP2) \\
\hline 24. & Distribution centre has office working hours suitable to you. & Empathy (EMP3) \\
\hline 25. & Distribution centre has field staff working hours suitable to you. & Empathy (EMP4) \\
\hline 26. & Methods designed for payments are convenient to you. & Empathy (EMP5) \\
\hline 27. & All required information is available on invoice provided & Reliability (REL7) \\
\hline 28. & Records are kept confidential. & Reliability (REL8) \\
\hline 29. & Payment information is kept confidential & Reliability (REL9) \\
\hline 30. & Distributor always provide warranty & Reliability (REL10) \\
\hline 31. & Distributor provides legal support when needed & ASS7) \\
\hline
\end{tabular}


TABLE III: DIMENSIONS AND ITEMS CONSTITUTING THE MODEL DEVELOPED

\begin{tabular}{|c|c|}
\hline S.No & $\underline{\text { ITEM }}$ \\
\hline \multicolumn{2}{|c|}{ RELIABILITY } \\
\hline 1. & Records are kept confidential. \\
\hline 2. & Payment information is kept cofidential \\
\hline \multicolumn{2}{|c|}{ ASSURANCE } \\
\hline 3. & Personnel in the distribution center are consistently courteous with you \\
\hline 4. & $\begin{array}{l}\text { Personnel in the distribution center have the knowledge to answer your } \\
\text { queries. }\end{array}$ \\
\hline 5. & $\begin{array}{l}\text { Personnel in the distribution center have the authority to solve your } \\
\text { problems. }\end{array}$ \\
\hline \multicolumn{2}{|c|}{ TANGIBLES } \\
\hline 6. & $\begin{array}{l}\text { Distribution center has modern equipment (Computers, air-conditioning } \\
\text { etc.). }\end{array}$ \\
\hline 7. & Distributor has sufficient physical facilities for storing drug products. \\
\hline 8. & The physical facilities at distribution center are visually clean. \\
\hline \multicolumn{2}{|c|}{ RESPONSIVENESS } \\
\hline 9. & Distributor responds immediately to your enquiries. \\
\hline 10. & Distributor responds immediately to your complaints. \\
\hline
\end{tabular}


FIGURE I: SUGGESTED PROCEDURE FOR DEVELOPING BETTER MEASURES

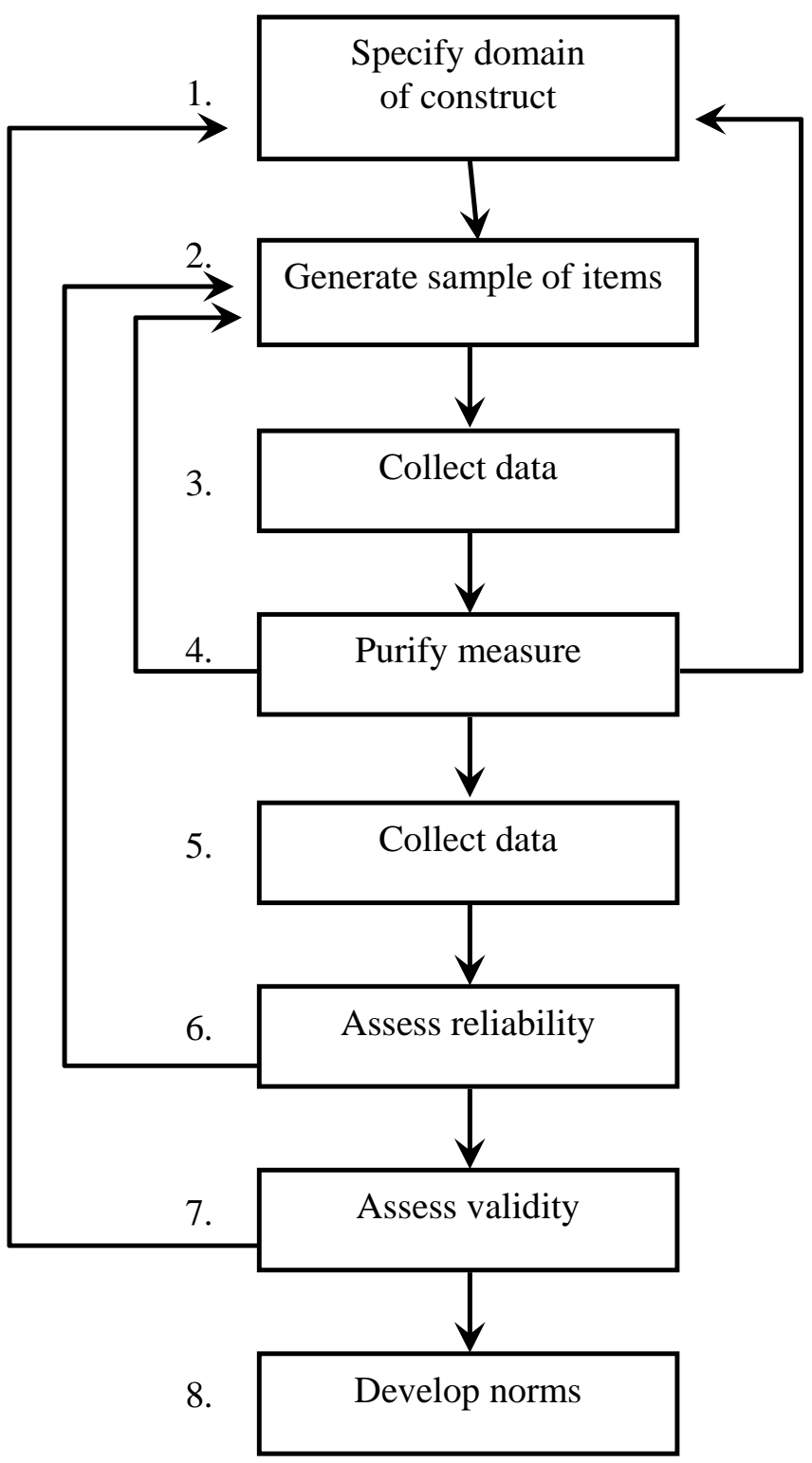

Literature search

Literature search

Experience survey

Insight stimulating examples

Critical incidents

Focus groups

Coefficient alpha

Factor analysis

Coefficient alpha

Split-half reliability

Multitrait-multimethod matrix Criterion validity

Average and other statistics summarizing distribution of scores

Source: Churchill (1979) 
FIGURE II: THEORETICAL FRAMEWORK FOR DEVELOPMENT OF SERVICE QUALITY SCALE

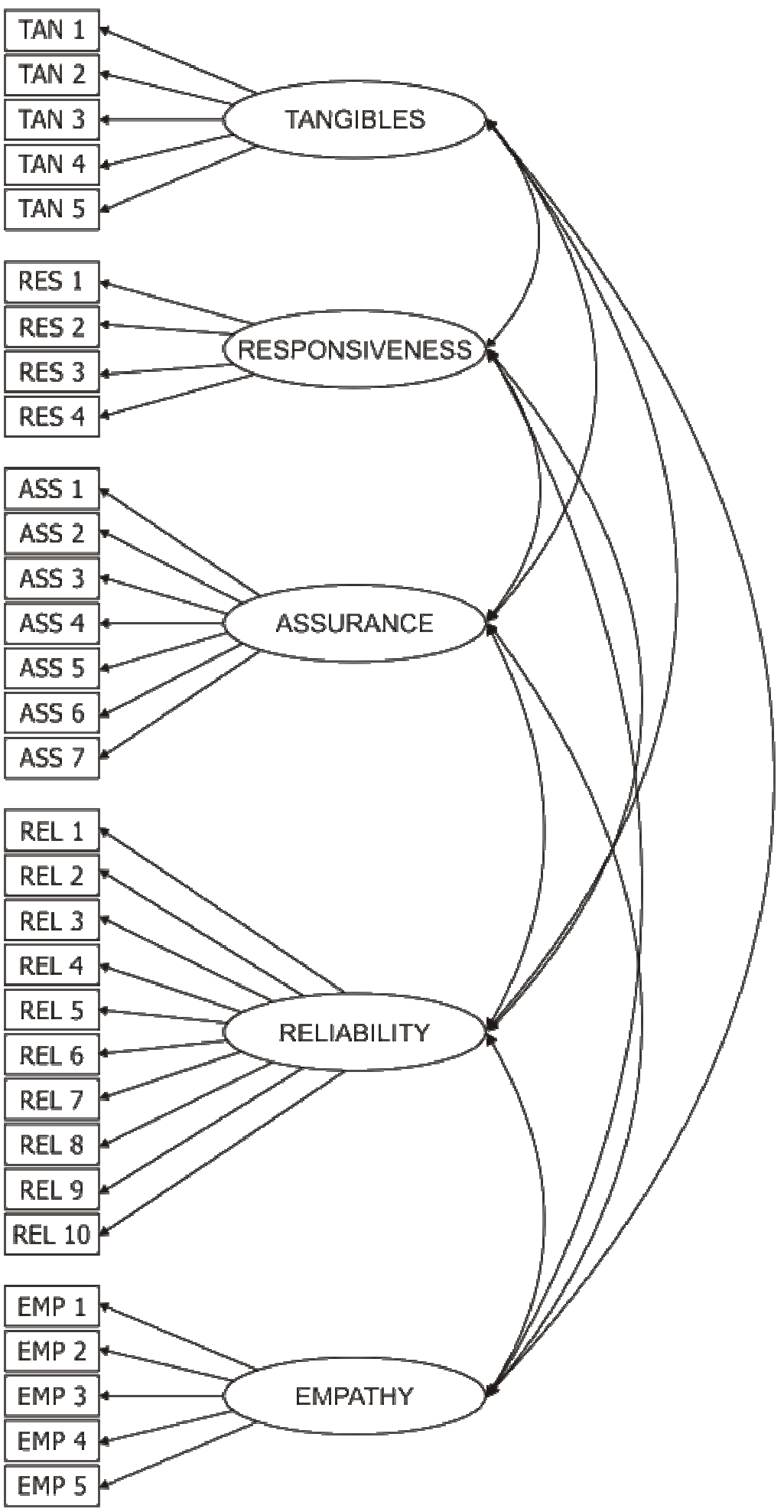


FIGURE III: CFA MODEL DEVELOPED USING AMOS 7.0
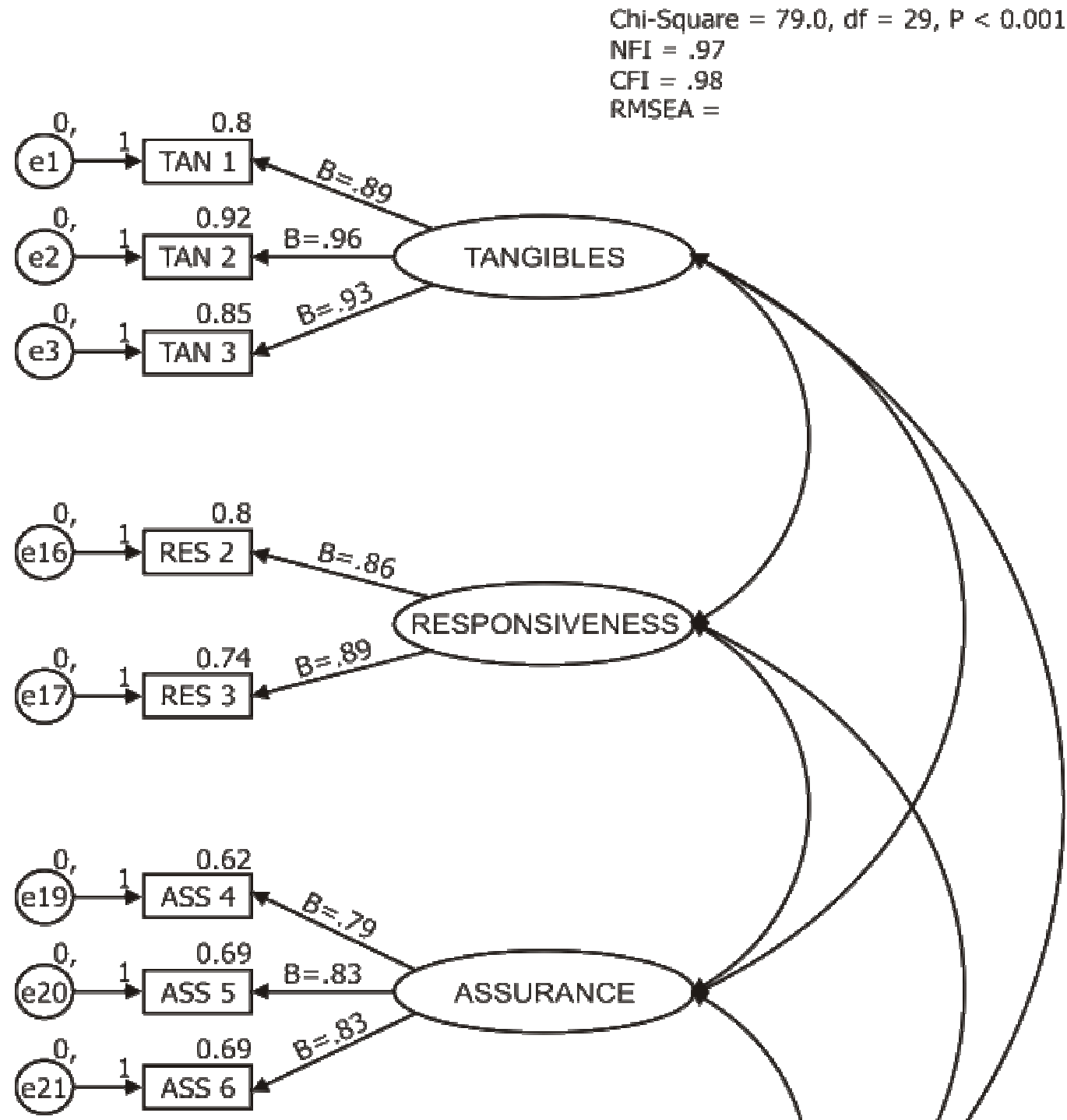

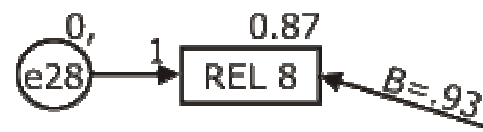

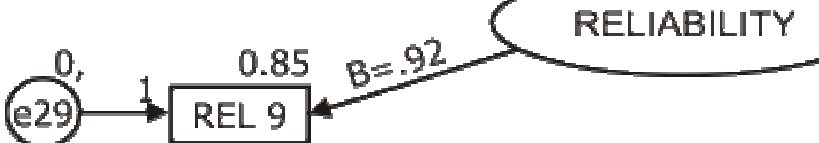


APPENDIX A: SEQUENCE WISE LIST OF DELETED ITEMS

\begin{tabular}{|c|c|c|c|}
\hline S.No & $\underline{\text { ITEM }}$ & $\begin{array}{l}\text { EXPLAINED } \\
\text { VARIANCE }\end{array}$ & $\begin{array}{l}\text { DELETION } \\
\underline{\text { STEP }}\end{array}$ \\
\hline 1. & $\begin{array}{l}\text { Personnel handling drugs are professional in } \\
\text { appearance. }\end{array}$ & $\overline{0.11}$ & $\overline{1}$ \\
\hline 2. & $\begin{array}{l}\text { All required information is available on } \\
\text { invoice provided }\end{array}$ & 0.19 & 1 \\
\hline 3. & $\begin{array}{l}\text { Distributor effectively handles the } \\
\text { counterfeit drugs issue. }\end{array}$ & 0.23 & 1 \\
\hline 4. & $\begin{array}{l}\text { Distribution centre has office working hours } \\
\text { suitable to you. }\end{array}$ & 0.24 & 1 \\
\hline 5. & $\begin{array}{l}\text { Distributor effectively handles the expired } \\
\text { drugs issue. }\end{array}$ & 0.21 & 2 \\
\hline 6. & $\begin{array}{l}\text { Temperature and humidity are controlled } \\
\text { during transportation of drugs. }\end{array}$ & 0.28 & 2 \\
\hline 7. & $\begin{array}{l}\text { When you have any problem, distributor } \\
\text { shows a sincere interest in solving it. }\end{array}$ & 0.33 & 2 \\
\hline 8. & $\begin{array}{l}\text { Distribution centre personnel's fulfil your } \\
\text { specific requirements }\end{array}$ & 0.39 & 2 \\
\hline 9. & $\begin{array}{l}\text { Distribution centre has field staff working } \\
\text { hours suitable to you. }\end{array}$ & 0.43 & 3 \\
\hline 10. & $\begin{array}{l}\text { Distributor provides legal support when } \\
\text { needed }\end{array}$ & 0.44 & 3 \\
\hline 11. & $\begin{array}{l}\text { Order taking methods (including frequency) } \\
\text { are accurate. }\end{array}$ & 0.47 & 3 \\
\hline 12. & Shipments contain wrong / damaged items. & 0.49 & 4 \\
\hline 13. & Shipments contain incorrect quantity. & 0.51 & 4 \\
\hline 14. & $\begin{array}{l}\text { Distribution centre personnel's give you } \\
\text { individual attention }\end{array}$ & 0.51 & 4 \\
\hline 15. & $\begin{array}{l}\text { Methods designed for payments are } \\
\text { convenient to you. }\end{array}$ & 0.53 & 4 \\
\hline 16. & $\begin{array}{l}\text { Vehicles used in transportation are visually } \\
\text { in a good condition. }\end{array}$ & 0.50 & 5 \\
\hline 17. & $\begin{array}{l}\text { Personnel at the distribution centre are } \\
\text { trained. }\end{array}$ & 0.55 & 5 \\
\hline 18. & $\begin{array}{l}\text { Order delivery methods (including } \\
\text { frequency) are accurate. }\end{array}$ & 0.56 & 5 \\
\hline 19. & $\begin{array}{l}\text { When distributor promises to deliver by } \\
\text { certain time, they do so. }\end{array}$ & 0.53 & 6 \\
\hline 20. & Distributor always provide warranty & 0.58 & 6 \\
\hline 21. & $\begin{array}{l}\text { Distributor provide services at short notice } \\
\text { (if required) }\end{array}$ & 0.59 & 6 \\
\hline
\end{tabular}

In $7^{\text {th }}$ Run, valid scale was developed. 